\title{
THE LANGTANG NATIONAL PARK: A PROPOSED FIRST BIOSPHERE RESERVE OF NEPAL
}

\author{
PURNA NATH MISHRA
}

Chairman, Nepal National Committee for MAB, Nepal

Proceedings of the South and Central Asian MAB Meeting of Experts on Environmental Conservation, Management and Research, Hikkaduwa, Sri Lanka 15-18 October 2002

\section{Introduction}

Nepal's topography makes the country unique in the world. Though a small country, it embodies a great diversity of flora and fauna due to its sharp altitudinal and climatic variations. So far, over 5,400 spp. of higher plant, $645 \mathrm{spp}$. of butterfly, 180 spp. of dragonfly, $186 \mathrm{spp}$. of fish, $175 \mathrm{spp}$. of herpetofauna, $858 \mathrm{spp}$. of bird and 185 spp. of mammal have been recorded from the country. In a global context these figures represent a contribution of $2.2 \%$ flowering plants, $4.2 \%$ butterflies, $2.2 \%$ fish, $1.4 \%$ herpetofauna, $8.5 \%$ birds and $4.2 \%$ mammals to the world's biodiversity. Conservation of biological diversity has long been realized in the form of creating protected areas free from major human interference. A comprehensive programme was started in 1970 for developing national parks and wildlife reserves in different parts of the country, which got statutory status in 1973 in the form of the National Parks and Wildlife Conservation Act of 1973.

The Royal Chitwan National Park as a first protected area of the country was established in 1973. Since then, 16 protected areas ( 8 national parks, 1 national park-cum-conservation area, 3 wildlife reserves, 3 conservation areas and 1 hunting reserve) have been established in the country, covering approximately 18 per cent of its total land area. Except for two conservation areas (Annapurna Conservation Area and Manaslu Conservation Area, which are run under the aegis of the King Mahendra Trust for Nature Conservation - a non-government organization), the rest are all government administered areas. Conservation areas like Annapurna, Manaslu and Kanchanchanga have an innovative programme that directly links conservation with sustainable development.

The country does not have a biosphere reserve. Therefore, the UNESCO MAB Committee in Nepal has recently initiated an activity to design the first biosphere reserve in the country. A working committee, consisting of well-qualified personnel involved in protected area management, forestry, university and other conservation sectors was established for this purpose. The members had discussed whether several potential sites within the country fulfill the general criteria for an area to be qualified for designation as a biosphere reserve (as mentioned in The Statutory Framework 
of the World Network of Biosphere Reserves). The Langtang National Park (LNP) was unanimously chosen as the potential biosphere reserve in the country.

\section{The Langtang National Park (LNP)}

It lies in the central Himalayan region of the country. Extremely rich in scenic beauty, it was designated as the first Himalayan National Park of the country in 1970-71. Gazetted in March 1976, the park is the second nearest park to Kathmandu, the capital of the country. The main aim of its establishment was to protect the central Himalayan ecosystem. Its area extends from $32 \mathrm{~km}$ north of Kathmandu to the Nepal-China border. Therefore, the park also provides an opportunity for bilateral coordination pertaining to natural resource management activities with China. The park boundaries were demarcated in 1979 , and encompass an area of $1,710 \mathrm{~km}^{2}$. The park is bisected eastwest to southeast by the Gosainkunda Lake $(4,300 \mathrm{~m})$ and Dorje Lhakpa $(6,988 \mathrm{~m})$ range in the north. Langtang Lirung $(7,245 \mathrm{~m})$ is the highest point in the park. The central Himalayan ecosystem of the park represents Tropical bioclimatic zone $(792 \mathrm{~m})$ to Nival zone $(7,245 \mathrm{~m})$.

Much scientific research has already been conducted in the park. LNP is extremely rich in biodiversity because it lies at the junction of eastern and western extremes of species distribution. So far, over 46 species of mammal, 345 species of bird, 11 species of herpetofauna, 30 species of fish, 70 species of butterfly and 10 species of spider had been recorded. It harbors more than 1,000 species of plants including 172 species used for human consumption and medical purposes, and 15 plants are endemic. Some of the globally endangered wildlife of the park includes snow leopard, clouded leopard, red panda, musk deer and leopard cat.

About 45 villages are situated within the park boundaries and 3,000 households depend on park resources, primarily for fuelwood and pasturage. Most of these villages are situated in the vicinity of the western and southern borders of the park. The park provides fodder and a grazing area for some 29,000 livestock. Pressure on the park's natural resources is becoming increasingly severe. Culturally, the area is a mixed home for several ethnic groups. The holy lake Gosainkunda (at $4,400 \mathrm{~m}$ ), which is sanctified to the Hindu god Siva, attracts some 8,000 Hindu and Buddhist pilgrims each summer from all over the Indian subcontinent. The lakes at Panch-Pokhari are also important pilgrimage sites. In addition, there are a number of monasteries, monuments and other places of religious and cultural importance elsewhere in the park as well.

LNP encloses the catchment of two major river systems: one draining west into the Trisuli River and the other east to the Sunkoshi River. It is rich in aquatic resources due to the presence of several streams and ponds at different elevations. LNP is visited by a comparatively large number of visitors $-6,501$ and 7,063 were the numbers of visitors in 1996/1997 and 1997/1998 respectively. The park already 
has its well-demarcated Buffer Zone area. Being an already well managed protected area of the country, LNP will definitely fulfil the three main functions expected of a biosphere reserve. 